\title{
Pengaruh Penerapan SIMDA, SAP, Motivasi Pegawai dan Kompetensi SDM Terhadap Kualitas Laporan Keuangan Pada Pemerintah Kabupaten Minahasa Selatan
}

\author{
CHRISTINA RUNTUWENE ${ }^{1}$, DAVID P. E. SAERANG ${ }^{2}$, JENNY MORASA ${ }^{3}$ \\ ${ }^{1,2,3}$ Program Magister Akuntansi, Fakultas Ekonomi dan Bisnis Universitas Sam Ratulangi \\ email: runtuwenechristina@gmail.com ${ }^{1}$,dpesaerang@gmail.com², jennymorasa@ hotmail.com³
}

\begin{abstract}
In order to achieve accountability and transparency, local governments are required to develop qualified financial reports. Qualified financial reports are considered as responsibilities of Local Government financial management. They should meet the qualitative characteristics of the financial statements: relevant, reliable, comparable and understandable. Factors that allegedly influence the quality of local government financial reports are the implementation of regional management information system (SIMDA) $\left(X_{1}\right)$, government accounting standards $(S A P)\left(X_{2}\right)$, employee motivation $\left(X_{3}\right)$, and human resources competency $\left(X_{4}\right)$. This study aims to examine the influence of implementation of regional management information system (SIMDA), government accounting standards (SAP), employee motivation, and human resources competency to the quality of financial reporting in South Minahasa regency. This is a quantitative research and data were collected by distributing questionnaires. In this study, samples were taken from 102 respondents. They were from 48 regional work unit (SKPD) in South Minahasa regency government. The data were analysed by multiple linear regression, data validity test, data reliability test, and classic assumption test. The data were processed by using Statical Product and Services Solution (SPSS) Software 22 version. The results shows that (1) the implementation of regional management information system (SIMDA) has a positive and significant effect to the quality of financial report of South Minahasa regency, (2) government accounting standards (SAP) has a positive and significant effect on the quality of financial report of South Minahasa regency, (3) employee motivation has a positive and significant effect on the quality of financial report of South Minahasa regency, and (4) human resources competency has a positive and significant effect on the quality of financial report of South Minahasa regency.
\end{abstract}

Keywords: Implementation of regional management information system (SIMDA), government accounting standards (SAP), employee motivation, human resources competency and quality of financial reporting

Abstrak. Dalam rangka mewujudkan akuntabilitas dan transparansi, pemerintah daerah dituntut untuk menyusun laporan keuangan yang berkualitas sebagai bentuk pertanggungjawaban atas pengelolaan keuangan daerah. Laporan keuangan yang berkualitas harus memenuhi karakteristik kualitatif laporan keuangan yaitu: relevan, andal, dapat dibandingkan dan dapat dipahami. Faktor-faktor yang diduga mempengaruhi kualitas laporan keuangan pemerintah daerah adalah penerapan sistem informasi manajemen daerah (SIMDA) $\left(\mathrm{X}_{1}\right)$, standar akuntansi pemerintahan (SAP) $\left(\mathrm{X}_{2}\right)$, motivasi pegawai $\left(\mathrm{X}_{3}\right)$, dan kompetensi SDM $\left(\mathrm{X}_{4}\right)$. Penelitian ini bertujuan untuk menguji pengaruh penerapan SIMDA, SAP, motivasi pegawai dan kompetensi SDM terhadap kualitas laporan keuangan pada pemerintah Kabupaten Minahasa Selatan. Jenis data yang digunakan pada penelitian ini adalah kuantitatif dan pengumpulan data digunakan kuesioner. Dalam penelitian ini diambil sampel dari 102 responden yang terdapat pada 48 SKPD di pemerintah Kabupaten Minahasa Selatan. Metode analisis data yang digunakan yaitu regresi linier berganda, dengan pengujian validitas data, uji reliabilitas data, uji asumsi klasik, dan analisis regresi berganda. Data diolah dengan menggunakan perangkat Software Statical Product and Services Solution (SPSS) versi 22. Hasil penelitian menunjukkan bahwa (1) penerapan SIMDA berpengaruh positif dan signifikan terhadap kualitas laporan keuangan pemerintah Kabupaten Minahasa Selatan, (2) SAP berpengaruh positif dan signifikan terhadap kualitas laporan keuangan pemerintah Kabupaten Minahasa Selatan, (3) motivasi pegawai berpengaruh positif dan signifikan terhadap kualitas laporan keuangan pemerintah Kabupaten Minahasa Selatan, dan (4) kompetensi SDM berpengaruh positif dan signifikan terhadap kualitas laporan keuangan pemerintah Kabupaten Minahasa Selatan.

Kata Kunci: Penerapan SIMDA, SAP, Motivasi Pegawai, Kompetensi SDM Dan Kualitas Laporan Keuangan. 


\section{Pendahuluan}

Dalam rangka mewujudkan good governance dan clean government dalam penyelenggaraan otonomi daerah, pemerintah daerah dituntut untuk meningkatkan akuntabilitas dan transparansi pengelolaan keuangan daerah serta penyelenggaraan pengelolaan keuangan daerah secara profesional sesuai yang ditetapkan dalam undang-undang. Implikasi dari adanya otonomi daerah terhadap akuntansi sektor publik adalah pemerintah daerah dituntut untuk mampu memberikan informasi keuangan kepada publik, DPRD, dan pihak-pihak yang menjadi stakeholder pemerintah daerah. Dalam Undang-Undang Nomor 17 Tahun 2003 tentang Keuangan Negara mewajibkan pemerintah daerah dan satuan kerja perangkat daerah selaku pengguna anggaran untuk menyusun laporan keuangan sebagai pertanggungjawaban pengelolaan keuangan. Hasil dari pengelolaan keuangan daerah dipertanggungjawabkan dalam laporan keuangan yang disajikan sesuai dengan Peraturan Pemerintah Nomor 71 Tahun 2010 tentang Standar Akuntansi Pemerintahan yang kemudian diperiksa oleh Badan Pemeriksa Keuangan (BPK) setiap tahunnya. Pada laporan keuangan yang mendapat opini WTP oleh BPK, dapat dikatakan bahwa laporan keuangan pemerintah daerah tersebut berkualitas dan komprehensif. Laporan keuangan yang berkualitas dan komprehensif dipengaruhi oleh berbagai aspek teknis diantaranya pemanfaatan teknologi atau sistem informasi, penerapan atas standar/peraturan yang berlaku serta sumber daya manusianya.

Dalam rangka memfasilitasi pemerintah daerah untuk mempersiapkan aparatnya menghadapi perubahan pelaksanaan tata kelola keuangan daerah, Badan Pengawasan Keuangan dan Pembangunan (BPKP) melalui Deputi Pengawasan Bidang Penyelenggaraan Keuangan Daerah menyusun suatu program aplikasi yang dapat digunakan oleh pemerintah daerah dalam rangka pengelolaan keuangan daerahnya. Program aplikasi dimaksud adalah program aplikasi komputer SIMDA atau sistem informasi manajemen daerah. Aplikasi komputer SIMDA mampu menghasilkan laporan keuangan dan informasi keuangan lainnya secara lebih komprehensif yang meliputi informasi mengenai posisi keuangan daerah, kondisi kinerja keuangan, dan akuntabilitas pemerintah daerah. Sistem pengelola keuangan daerah berbasis teknologi informasi ini dapat membantu pemerintah dalam menghasilkan informasi keuangan yang relevan, cepat, akurat, lengkap dan dapat diuji kebenarannya sehingga diharapkan dengan diterapkannya aplikasi SIMDA mampu meningkatkan tingkat opini BPK terhadap LKPD. Hal tersebut semakin didukung dengan pernyataan dari Deputi Kepala BPKP Bidang Pengawasan Penyelenggaraan Keuangan Daerah yang menyatakan bahwa dari jumlah pemerintah daerah yang memperoleh opini WTP pada tahun 2014 yakni sebanyak 252 pemerintah daerah telah meningkat menjadi 311 pemerintah daerah pada tahun 2015 dan sekitar $81 \%$ atau 253 pemerintah daerah tersebut telah menggunakan aplikasi SIMDA (BPKP, 2017, berita seputar BPKP dan pengawasan).

Hal yang mendasar dan penting lainnya dalam pengelolaan keuangan daerah adalah pemahaman akan standar yang diterapkan. Dalam penelitian sebelumnya, Tarigan (2013) menyatakan bahwa penerapan standar akuntansi pemerintahan (SAP) berbasis akrual merupakan salah satu program reformasi birokrasi, dimana pemerintahan yang selama ini kurang akuntabel dalam hal pengelolaan keuangan, dituntut menyampaikan laporan keuangan yang komprehensif dan handal kepada seluruh pengguna. Menurut Peraturan Pemerintah Nomor 71 Tahun 2010, standar akuntansi pemerintahan (SAP) adalah prinsip-prinsip akuntansi yang diterapkan dalam menyajikan laporan keuangan pemerintah, yang terdiri atas laporan keuangan pemerintah pusat (LKPP) dan laporan keuangan pemerintah daerah (LKPD. Namun, dalam pemeriksaan LKPD TA. 2015 pada tahun 2016, BPK menyatakan masih ditemukan penyajian akun yang tidak sesuai dengan SAP untuk: 1) akun aset tetap pada 188 pemerintah daerah berupa aset tetap tanah untuk gedung dan bangunan, jalan dan saluran irigasi belum dicatat, 2) beban-LO pada 77 pemerintah daerah berupa kesalahan penganggaran yang tidak dapat dikoreksi ke beban-LO sehingga penyajian beban-LO tidak dapat diukur dengan tepat, 3) belanja daerah pada 67 pemerintah daerah berupa belanja hibah dan belanja bantuan sosial direalisasikan untuk kepentingan yang tidak sesuai dengan tujuannya (BPK, 2016, IHPS I tahun 2016).

Unsur lain yang berperan penting dalam pengelolaan keuangan adalah motivasi dan kompetensi SDM. Motivasi merupakan salah satu faktor yang dapat mempengaruhi kinerja pegawai, karena seseorang belum tentu bersedia untuk mengerahkan segenap potensi yang dimilikinya untuk mencapai tujuan organisasi, sehingga diperlukannya pendorong agar seseorang mau menggunakan seluruh potensinya. Daya pendorong tersebut adalah motivasi (Kadarisman, 2012:278).

Hal lain yang dapat mempengaruhi kualitas laporan keuangan adalah kompetensi. Kompetensi adalah segala akal, pengetahuan, skill atau pengalaman yang dimiliki seseorang dalam melaksanakan pekerjaannya. Prinsip the right man in the right place dapat menjadi kunci sukses sebuah organisasi 
dalam mencapai tujuan. Namun, dalam hasil pemeriksaan BPK tahun 2014 dan 2015, ditemukan bahwa penempatan SDM pengelola keuangan masih tidak sesuai dengan bidangnya. Sekitar 77,98\% atau 85 pemerintah daerah melakukan penempatan pegawai pengelola keuangan tanpa mempertimbangkan tugas, fungsi dan kompetensi sebagai pengelola keuangan (BPK, 2015, Pendapat $\mathrm{BPK})$.

Berdasarkan uraian sebelumnya, maka akan dilakukan penelitian dengan objek penelitian yaitu pemerintah Kabupaten Minahasa Selatan. Berdasarkan ikhtisar hasil pemeriksaan semester (IHPS), BPK RI memberikan opini TMP pada pemeriksaan LKPD TA. 2004-2007, opini TW pada pemeriksaan LKPD TA. 2008-2010, opini TMP pada pemeriksaan LKPD TA. 20011-2012, opini TW pada pemeriksaan LKPD TA. 2013, opini WDP pada pemeriksaan LKPD TA. 2014-2015, dan opini WTP-DPP pada pemeriksaan LKPD TA. 2016. Dalam rangka peningkatan pengelolaan keuangan daerah, pemerintah Kabupaten Minahasa Selatan telah menerapkan aplikasi SIMDA guna meningkatkan kinerja dalam pengelolaan keuangan daerah. Penerapan aplikasi SIMDA dilakukan dengan mengikuti rekomendasi dari BPK untuk menggunakan sistem informasi yang mampu mendukung pengelolaan keuangan daerah. Dalam pemeriksaan LKPD Kabupaten Minahasa Selatan TA. 2015 pada tahun 2016, BPK RI masih menemukan kelemahan dalam penyajian laporan keuangan yang tidak sesuai dengan standar akuntansi pemerintahan, kelemahan tersebut ditemukan pada penyajian akun aset tetap, aset lainnya, belanja barang, belanja modal, dan belanja daerah lainnya (BPK, 2016, IHPS I tahun 2016). Berdasarkan uraian diatas, maka penelitian ini berjudul "Pengaruh Penerapan SIMDA, SAP, Motivasi Pegawai dan Kompetensi SDM terhadap Kualitas Laporan Keuangan pada Pemerintah Kabupaten Minahasa Selatan".

\section{Metode Penelitian}

Penelitian ini menggunakan metode penelitian kuantitatif. Jenis data yang dianalisis dalam penelitian ini adalah data primer yang dikumpulkan melalui kuisioner dari responden. Isi kuisioner adalah daftar pernyataan terstruktur yang ditujukan pada responden yang dipilih secara purposive. Populasi dalam penelitian ini adalah Pegawai Negeri Sipil (PNS) di lingkungan pemerintah Kabupaten Minahasa Selatan yang menjadi bendahara Satuan Kerja Perangkat Daerah (SKPD), Pejabat Penatausahaan Keuangan (PPK) SKPD, dan PNS bidang akuntansi Dinas Pengelolaan Keuangan, Pendapatan dan Aset Daerah Kabupaten Minahasa Selatan selaku SKPKD. Adapun metode pengambilan sampel yang digunakan adalah metode purposive sampling. Subjek penelitian yang dijadikan sampel adalah populasi yang memenuhi kriteria dengan kriteria yang ditetapkan adalah pernah menyusun laporan keuangan pemerintah.

\section{Uji Asumsi Klasi}

Uji asumsi klasik digunakan untuk mengetahui ada tidaknya normalitas residual, multikolinieritas, dan heteroskedastisitas pada model regresi. Pada model regresi ini, uji autokorelasi tidak dilakukan karena data pada penelitian ini berupa data cross section yaitu kuesioner. Harus terpenuhinya asumsi klasik agar diperoleh model regresi dengan estimasi yang tidak bias dan pengujian dapat dipercaya. Apabila ada satu syarat saja yang tidak terpenuhi, hasil analisis regresi tidak dapat dikatakan bersifat BLUE (Best Linier Unbiased Estimator) (Priyatno, 2014:89). Dalam penelitian ini, diperoleh hasil data yang diuji berdistribusi normal, tidak terjadi multikolinieritas antar variable independen, dan tidak terjadi gejala heteroskedastisitas pada model regresi.

\section{Metode Analisis}

Pengujian hipotesis dalam penelitian ini dilakukan dengan menggunakan model analisis regresi berganda. Persamaan regresinya adalah:

$$
\mathrm{Y}=\alpha+\beta_{1} \mathrm{X}_{1}+\beta_{2} \mathrm{X}_{2}+\beta_{3} \mathrm{X}_{3}+\beta_{4} \mathrm{X}_{4}+\mathrm{e}
$$

$$
\begin{aligned}
& \mathrm{Y}=\text { Kualitas laporan keuangan } \\
& \alpha=\text { Konstanta } \\
& \beta_{1 .} \beta_{2} \beta_{3} \beta_{4}=\text { Koefisien regresi } \\
& \mathrm{e}=\text { Error }
\end{aligned}
$$

$$
\begin{aligned}
& \mathrm{X}_{1}=\text { Penerapan SIMDA } \\
& \mathrm{X}_{2}=\text { SAP } \\
& \mathrm{X}_{3}=\text { Motivasi Pegawai } \\
& \mathrm{X}_{4}=\text { Kompetensi SDM }
\end{aligned}
$$




\section{Hasil Penelitian dan Pembahasan}

\section{Analisis Regresi Berganda}

\begin{tabular}{|c|c|c|c|c|c|c|}
\hline \multicolumn{7}{|c|}{ Coefficients $^{\mathrm{a}}$} \\
\hline \multirow{2}{*}{\multicolumn{2}{|c|}{ Model }} & \multicolumn{2}{|c|}{ Unstandardized Coefficients } & $\begin{array}{l}\text { Standardized } \\
\text { Coefficients }\end{array}$ & \multirow[b]{2}{*}{$\mathrm{t}$} & \multirow[b]{2}{*}{ Sig. } \\
\hline & & $\mathrm{B}$ & Std. Error & Beta & & \\
\hline \multirow[t]{5}{*}{$\overline{1}$} & (Constant) & -.488 & 3.155 & & -.155 & .877 \\
\hline & Penerapan SIMDA & .464 & .070 & .353 & 6.592 & .000 \\
\hline & SAP & .342 & .049 & .429 & 6.926 & .000 \\
\hline & Motivasi Pegawai & .210 & .064 & .156 & 3.290 & .001 \\
\hline & Kompetensi SDM & .185 & .065 & .176 & 2.840 & .005 \\
\hline
\end{tabular}

a. Dependent Variable: Kualitas Laporan Keuangan

Sumber: Data hasil pengolahan SPSS 22 (2017)

Sehingga didapatkan persamaan regresi sebagai berikut.

$$
Y=-0,488+0,464 X_{1}+0,342 X_{2}+0,210 X_{3}+0,185 X_{4}+e
$$

Berdasarkan hasil analisis regresi berganda, diperoleh hasil nilai koefisien regresi dari variabel Penerapan SIMDA $\left(\mathrm{X}_{1}\right)$ bernilai positif, yaitu 0,464 ; ini dapat diartikan bahwa penerapan SIMDA memberikan kontribusi sebesar $46,4 \%$ terhadap kualitas laporan keuangan. Variabel SAP $\left(\mathrm{X}_{2}\right)$ nilai koefisien regresi diperoleh bernilai positif yaitu 0,342; ini dapat diartikan bahwa SAP memberikan kontribusi sebesar 34,2\% terhadap kualitas laporan keuangan. Variabel Motivasi Pegawai $\left(\mathrm{X}_{3}\right)$ nilai koefisien regresi diperoleh bernilai positif yaitu 0,210; ini dapat diartikan bahwa motivasi pegawai memberikan kontribusi sebesar 21\% terhadap kualitas laporan keuangan. Variabel Kompetensi SDM $\left(\mathrm{X}_{4}\right)$ nilai koefisien regresi diperoleh bernilai positif yaitu 0,185 artinya kompetensi SDM memberikan kontribusi sebesar 18,5\% terhadap kualitas laporan keuangan.

\section{Uji t}

Uji t digunakan untuk mengetahui pengaruh masing-masing variable independen terhadap variable dependen. Kriteria pengujian yang digunakan adalah jika $p$ value $<0,05$, maka Ho ditolak dan jika $p$ value $>0,05$, maka Ho diterima. Pada penelitian ini menunjukkan hasil nilai $p$ value $<0,05$ sehingga variabel penerapan SIMDA, SAP, motivasi pegawai dan kompetensi SDM secara parsial berpengaruh terhadap kualitas laporan keuangan.

\section{Uji F}

Uji $\mathrm{F}$ digunakan untuk mengetahui ada tidaknya pengaruh simultan variabel-variabel independen terhadap variable dependen. Hasil uji F memperoleh hasil probabilitas 0,000 lebih kecil dari 0,05. Hal ini menunjukkan bahwa secara simultan variabel penerapan SIMDA, SAP, motivasi pegawai dan kompetensi SDM berpengaruh terhadap kualitas laporan keuangan.

\section{Koefisien Determinasi}

Pada regresi yang menggunakan lebih dari dua variabel independen, untuk mengukur sumbangan pengaruh maka digunakan Adjusted $R$ Square sebagai koefisien determinasi (Priyatno, 2014:156). Hasil yang diperoleh adjusted R square (koefisien determinasi yang telah disesuaikan) adalah 0,824 . Nilai ini menunjukkan bahwa $82,4 \%$ variasi kualitas laporan keuangan dapat dijelaskan dari keempat variabel independen yaitu penerapan SIMDA, SAP, motivasi pegawai, dan kompetensi SDM, sedangkan sisanya 17,6\% dijelaskan oleh sebab lain diluar model.

\section{Pengaruh Penerapan SIMDA Terhadap Kualitas Laporan Keuangan}

Hasil pengujian hipotesis pada penelitian ini menjawab bahwa penerapan SIMDA berpengaruh terhadap kualitas laporan keuangan. Hasil pengujian statistik menunjukkan bahwa nilai koefisien regresi variabel penerapan SIMDA adalah 0,464, artinya dengan adanya penerapan SIMDA maka kualitas laporan keuangan pemerintah Kabupaten Minahasa Selatan meningkat 46,4\%. Nilai ini 
signifikan pada tingkat signifikansi 0,05 dengan $p$ value 0,000 . Hal ini didukung dengan dengan hasil perhitungan nilai $\mathrm{t}_{\text {hitung }} 6,592>\mathrm{t}_{\text {tabel }} 1,985$.

Hal ini menunjukkan bahwa penerapan SIMDA berpengaruh signifikan terhadap kualitas laporan keuangan. Dengan demikian para pengelola keuangan di tingkat SKPD dan SKPKD pada pemerintah Kabupaten Minahasa Selatan semakin terbantu dalam melaksanakan tugasnya karena dengan adanya aplikasi SIMDA mempermudah dalam menghasilkan laporan keuangan yang mampu memenuhi karakteristik kualitiatif yakni relevan, andal, dapat dibandingkan dan dapat dipahami.

Hasil tersebut sejalan dengan perkembangan teknologi informasi yang semakin pesat yang juga mempengaruhi sistem pengolahan data dan informasi pada entitas yang melakukan pengelolaan dan pelaporan data keuangan. Dalam rangka pengolahan data keuangan yang efektif dan efisien, diperlukan sistem informasi yang terintegrasi, dapat diandalkan, cepat dan akurat sehingga sistem yang terintegrasi secara menyeluruh dapat menghasilkan informasi yang andal dan relevan.

Dalam teori Technology Acceptance Model beranggapan bahwa dalam penerapan sistem informasi, para pengguna selalu mempertimbangkan manfaat dari penerapan sistem informasi tersebut. Unsur kegunaan (usefulness) dan kemudahan (ease of use) menjadi pertimbangan bahwa dengan menerapkan sistem informasi dapat mempengaruhi kinerja seseorang dalam melaksanakan tugas dan pekerjaannya (Jogiyanto, 2007:114). Dalam penerapan SIMDA unsur kegunaan (usefulness) dapat terpenuhi karena aplikasi SIMDA merupakan sistem berbasis aplikasi teknologi yang dikembangkan guna mencapai akuntabilitas bagi pemerintah daerah baik di entitas pelaporan (SKPKD) dan entitas akuntansi (SKPD). Aplikasi ini dapat membantu pemerintah daerah mulai dari penyusunan perencanaan dan penganggaran, pelaksanaan dan penatausahaan APBD hingga pertanggungjawaban APBD.

Begitu pula dengan unsur kemudahan (ease of use) karena fitur-fitur dalam aplikasi SIMDA yang sederhana sehingga mudah dimengerti dan dipelajari. Transaksi keuangan pemerintah daerah seharihari dapat secara otomatis dihasilkan. Dengan demikian dapat dikatakan aplikasi SIMDA merupakan sistem yang terintegrasi secara menyeluruh dan mampu menghasilkan informasi yang handal dan relevan sehingga mampu memberi output laporan keuangan yang berkualitas.

Hal ini juga terbukti dari opini yang diberikan BPK terhadap LKPD Kabupaten Minahasa Selatan. Sejak berdiri menjadi daerah otonom pada tahun 2003 hingga tahun 2014, hasil opini BPK RI atas LKPD Kabupaten Minahasa Selatan adalah opini TMP (Tidak Memberikan Pendapat) dan TW (Tidak Wajar) namun setelah menerapkan SIMDA secara utuh terjadi peningkatan opini BPK RI terbukti dari hasil pemeriksaan LKPD TA. 2014 pada tahun 2015 dan LKPD TA. 2015 pada tahun 2016 yang mendapatkan opini WDP atau wajar dengan pengecualian serta pada pemeriksaan LKPD TA. 2016 pada tahun 2017 yang mendapatkan opini WTP-DPP atau wajar tanpa pengecualian dengan paragaraf penjelasan. Hal itu menunjukkan penerapan SIMDA pada pemerintah Kabupaten Minahasa Selatan, telah mampu meningkatkan kinerja para pengelola keuangan di tingkat SKPD dan SKPKD dalam menghasilkan laporan keuangan yang berkualitas sehingga berdampak pada peningkatan opini BPK atas LKPD Kabupaten Minahasa Selatan.

\section{Pengaruh SAP Terhadap Kualitas Laporan Keuangan}

Hasil pengujian hipotesis pada penelitian ini menjawab bahwa SAP berpengaruh terhadap kualitas laporan keuangan. Hasil pengujian statistik menunjukkan bahwa nilai koefisien regresi variabel SAP adalah 0,342, artinya SAP memberikan kontribusi sebesar 34,2\% terhadap kualitas laporan keuangan pemerintah Kabupaten Minahasa Selatan. Nilai ini signifikan pada tingkat signifikansi 0,05 dengan $p$ value 0,000 . Hal ini didukung dengan dengan hasil perhitungan nilai $t_{\text {hitung }} 6,926>t_{\text {tabel }} 1,985$.

Hal ini menunjukkan bahwa variabel SAP berpengaruh positif dan signifikan terhadap kualitas laporan keuangan. Hal tersebut menggambarkan penerapan SAP di Kabupaten Minahasa Selatan telah cukup baik, namun belum maksimal, karena hanya 34,2\% kontribusi SAP terhadap kualitas laporan keuangan. Hal tersebut dipengaruhi karena pengelola keuangan di tingkat SKPD yang ada di Kabupaten Minahasa Selatan sebagian besar tidak memiliki latar belakang pendidikan akuntansi, sehingga pemahaman dan penerapan SAP berbasis akrual di tingkat SKPD belum maksimal.

Berdasarkan ikhtisar hasil pemeriksaan semester (IHPS) I tahun 2016, BPK RI masih menemukan kelemahan dalam penyajian laporan keuangan pemerintah Kabupaten Minahasa Selatan yang tidak sesuai dengan standar akuntansi pemerintahan, kelemahan tersebut ditemukan pada penyajian akun aset tetap, aset lainnya, belanja barang, belanja modal, dan belanja daerah lainnya (BPK, 2016, IHPS I tahun 2016). Hal senada juga disampaikan oleh Sekretaris Dinas Pengelolaan Keuangan, Pendapatan dan Aset Daerah (DPKPAD) Kabupaten Minahasa Selatan, masih ada permasalahan yang ditemukan 
oleh BPK diantaranya mengenai pengelolaan TGR (Tuntutan Ganti Rugi) dan manajemen aset tetap. Hal tersebut perlu ditindaklanjuti guna peningkatan kualitas penyajian laporan keuangan yang sesuai dengan SAP.

Pemerintah Kabupaten Minahasa Selatan dalam rangka meningkatkan penerapan SAP telah melakukan sosialisasi dan bimbingan teknis yang melibatkan pengelola keuangan di tingkat SKPD serta menetapkan peraturan Bupati Minahasa Selatan No. 13 Tahun 2016 tentang Kebijakan Akuntansi. Pemahaman akan standar akuntansi yang diterapkan, dapat meningkatkan kualitas laporan keuangan yang disajikan. Sesuai dengan teori yang dikemukakan oleh Belkaoui bahwa standar akuntansi yang ada, dapat memberi pedoman bagi para pengelola keuangan dalam melaksanakan pekerjaannya dan mendukung dalam penyajian informasi posisi keuangan yang dapat dipercaya kebenarannya dan memiliki daya banding. Informasi yang dapat dipercaya kebenarannya akan dianggap berkualitas (berguna) bagi pemakai maupun para pengambil keputusan dalam pengambilan keputusan.

Teori kegunaan keputusan dalam pengujian ini digambarkan lewat hubungan antara SKPKD dan SKPD dalam menyajikan komponen-komponen informasi akuntansi yang nantinya digunakan oleh pengguna informasi dalam pengambilan keputusan. SKPD selaku entitas akuntansi melakukan proses akuntansi dan menyiapkan laporan keuangan menurut SAP selanjutnya SKPKD selaku entitas pelaporan melakukan konsolidasi atas laporan keuangan SKPD dan PPKD sehingga menghasilkan laporan keuangan konsolidasi yang kemudian disampaikan kepada Kepala Daerah dan digunakan untuk evaluasi serta pengambilan keputusan yang berkaitan dengan alokasi sumber daya ekonomi.

Dalam teori kegunaan-keputusan beranggapan bahwa laporan keuangan yang disajikan harus memenuhi karakteristik kualitas informasi. Unsur kualitas laporan keuangan seperti relevan dan reliabel harus terpenuhi dalam suatu laporan keuangan, sehingga laporan keuangan yang disajikan diyakini berkualitas dan dapat digunakan dalam pengambilan keputusan. Hal tersebut sesuai dengan SAP yang diatur dalam Peraturan Pemerintah Nomor 71 Tahun 2010 bahwa laporan keuangan pemerintah daerah harus memenuhi karakteristik kualitas laporan keuangan yakni relevan, andal, dapat dibandingkan dan dapat dipahami sehingga dengan memenuhi karakteristik tersebut, laporan keuangan pemerintah daerah semakin berkualitas atau berguna bagi pemakai dan para pengambil keputusan.

\section{Pengaruh Motivasi Pegawai Terhadap Kualitas Laporan Keuangan}

Hasil pengujian hipotesis pada penelitian ini menjawab bahwa motivasi pegawai berpengaruh terhadap kualitas laporan keuangan. Hasil pengujian statistik menunjukkan bahwa nilai koefisien regresi variabel motivasi pegawai adalah 0,210 , artinya motivasi pegawai memberi kontribusi sebesar $21 \%$ atas kualitas laporan keuangan pemerintah Kabupaten Minahasa Selatan. Nilai ini signifikan pada tingkat signifikansi 0,05 dengan $p$ value 0,001 . Hal ini didukung dengan hasil perhitungan nilai $t_{\text {hitung }} 3,290>t_{\text {tabel }}$ 1,985. Hal ini menunjukkan bahwa motivasi pegawai berpengaruh positif dan signifikan terhadap kualitas laporan keuangan.

Dalam dunia kerja, motivasi kerja merupakan hal yang sangat dibutuhkan karena motivasi dapat menjadi pendorong seseorang dalam bekerja. Pekerjaan yang mampu memenuhi unsur kebutuhan seseorang dalam bekerja dapat menjadi motivasi seseorang dalam bekerja. Dalam teori kebutuhan Maslow beranggapan bahwa tindakan manusia pada hakikatnya adalah untuk memenuhi kebutuhannya. Unsur kebutuhan seperti penghasilan yang memuaskan (physiological needs), hubungan kerja yang baik dan tidak kaku (acceptance needs), mendapat penghargaan atau pengakuan (esteem needs) dan pengembangan diri atas potensinya (self actualization) yang dapat terpenuhi lewat tugas dan pekerjaannya maka akan mempengaruhi kinerja seseorang sebagai respon atas tugas pekerjaan yang dilakukan.

Teori keagenan digambarkan lewat peran pemerintah daerah dalam hal ini diwakili oleh bendahara SKPD, PPK SKPD dan pegawai bidang akuntansi SKPKD yang merupakan orang-orang yang telah dipilih untuk melakukan pengelolaan keuangan, bertanggung jawab untuk menyusun laporan pertanggungjawaban keuangan dalam rangka akuntabilitas publik. Mereka yang dipilih oleh atasannya artinya dipercaya mampu melaksanakan tugas yang telah diamanahkan. Sehingga hal ini dapat menjadi ajang pembuktian (self actualization) bagi para pengelola keuangan (agents) tersebut untuk membuktikan bahwa mereka adalah orang yang tepat untuk melakukan pekerjaan tersebut.

Motivasi tersebut dapat menjadi pendorong bagi para pengelola keuangan tersebut untuk menghasilkan laporan keuangan yang akuntabel. Laporan keuangan yang akuntabel menunjukkan bahwa mereka telah mampu menjalankan amanah yang diberikan atasannya dengan baik. Terlebih lagi 
menjadi suatu kepuasan bagi para pengelola keuangan tersebut jika hasil pekerjaan yakni laporan keuangan tersebut mendapat reward dari BPK berupa opini WDP bahkan WTP (esteem needs).

Opini BPK seolah menjadi tolak ukur kinerja pengelolaan keuangan selama satu periode tahun tersebut. Jika opini yang diperoleh memuaskan artinya mereka telah melaksanakan tugas dan tanggung jawabnya dengan baik. Sehingga secara tidak langsung hal tersebut menjadi motivasi bagi setiap pengelola keuangan baik ditingkat SKPD maupun SKPKD untuk terus meningkatkan kinerjanya sehingga laporan pertanggungjawaban keuangan yang dihasilkan lebih berkualitas.

\section{Pengaruh Kompetensi SDM Terhadap Kualitas Laporan Keuangan}

Hasil pengujian hipotesis pada penelitian ini menjawab bahwa kompetensi SDM berpengaruh terhadap kualitas laporan keuangan. Hasil pengujian statistik menunjukkan bahwa nilai koefisien regresi variabel kompetensi SDM adalah 0,185, artinya kompetensi SDM memberi kontribusi sebesar 18,5\% atas kualitas laporan keuangan pemerintah Kabupaten Minahasa Selatan. Nilai ini signifikan pada tingkat signifikansi 0,05 dengan $p$ value 0,005 . Hal ini didukung dengan hasil perhitungan nilai $\mathrm{t}_{\text {hitung }} 2,840>\mathrm{t}_{\text {tabel }} 1,985$. Hasil ini menunjukkan bahwa kompetensi SDM berpengaruh positif dan signifikan terhadap kualitas laporan keuangan.

Berdasarkan hasil penelitian tersebut, dapat dilihat bahwa kompetensi SDM berpengaruh terhadap kualitas laporan keuangan namun kontribusinya hanya 18,5\%. Hal tersebut dapat dipahami karena sebagian besar pengelola keuangan di tingkat SKPD pada pemerintah Kabupaten Minahasa Selatan bukan berasal dari latar belakang akuntansi. Hal tersebut tentunya mengakibatkan masih belum maksimalnya kontribusi kompetensi SDM terhadap kualitas laporan keuangan.

Hal ini sesuai dengan hasil pemeriksaan BPK tahun 2014 dan 2015, dengan ditemukannya bahwa penempatan SDM pengelola keuangan pada pemerintah daerah masih tidak sesuai dengan bidangnya. Sekitar 77,98\% atau 85 pemerintah daerah melakukan penempatan pegawai pengelola keuangan tanpa mempertimbangkan tugas, fungsi dan kompetensi sebagai pengelola keuangan (BPK, 2015, Pendapat BPK).

Dalam teori yang dikemukakan oleh McClelland menyatakan bahwa kompetensi bukan hanya kemampuan akademis seseorang. McClelland menyatakan bahwa pengetahuan dan keterampilan berpengaruh terhadap kinerja seseorang, namun yang lebih berperan terhadap kinerja seseorang adalah karakteristik lain seperti peran sosial, citra diri, sifat dan motif yang mempengaruhi sikap kerja seseorang (Sedarmayanti, 2017).

Sikap kerja dapat menjadi kompetensi terkuat dalam meningkatkan kinerja. Seseorang dengan sikap kerja yang tinggi, walaupun ditugaskan dengan pekerjaan yang tidak sesuai dengan bidangnya, mampu beradaptasi dan memberi output yang memuaskan.

Penempatan pengelola keuangan pada pemerintah Kabupaten Minahasa Selatan yang cenderung tidak memperhatikan latar belakang akademis menuntut adanya adaptasi dengan kondisi tersebut. Para pengelola keuangan tersebut harus mampu mengembangkan pengetahuannya lewat sosialisasi dan bimbingan teknis terkait pengelolaan keuangan khususnya SAP berbasis akrual yang diselenggarakan pemerintah Kabupaten Minahasa Selatan setiap tahunnya. Disamping itu juga, dengan diterapkannya aplikasi SIMDA pada pemerintah Kabupaten Minahasa Selatan, para pengelola keuangan tersebut harus mampu mengembangkan keterampilannya dalam menyusun laporan keuangan baik LRA, LO, LPE, neraca, dan CaLK di tingkat SKPD dengan memahami aplikasi SIMDA sehingga memudahkan dalam menyusun dan menyajikan laporan keuangan yang berkualitas.

Dalam teori yang dikemukakan oleh Spencer dan Spencer beranggapan bahwa kompetensi dapat mempengaruhi kinerja seseorang. Artinya jika para pengelola keuangan mempunyai kompetensi yang tinggi, maka akan mempunyai kinerja yang tinggi dan output yang dihasilkan yakni laporan keuangan semakin berkualitas. Hal tersebut sesuai dengan kompetensi teknis PNS yang tercantum dalam Peraturan Kepala Badan Kepegawaian Negara No. 8 Tahun 2013 yang berbunyi setiap PNS memerlukan aspek pengetahuan, keterampilan, dan sikap kerja dalam melaksanakan tugas-tugas jabatannya.

Seseorang yang ditempatkan sesuai dengan kompetensinya tentunya akan lebih mampu mengambil keputusan dan memecahkan masalah yang berkaitan dengan pekerjaannya. Hal tersebut juga dapat membentuk pribadi yang lebih percaya diri dalam melakukan pekerjaannya sehingga dapat meningkatkan prestasi dalam pekerjaannya.

Teori keagenan secara umum dalam pengujian ini terlihat lewat hubungan antara pengelola keuangan dengan atasannya dimana baik PPK SKPD, bendahara SKPD dan pegawai bidang akuntansi SKPKD merupakan orang yang diangkat, atau dipilih oleh atasannya untuk melakukan tugas 
pengelolaan keuangan. Hubungan keagenan semakin terlihat disaat seseorang yang telah diangkat atau dipilih untuk melaksanakan suatu tugas, bisa saja suatu saat di promosi atau di nonaktifkan atau dimutasi ke bidang pekerjaan lainnya. Sehingga menjadi suatu hal yang penting bagi para pengelola keuangan tersebut untuk terus meningkatkan kinerjanya sehingga memperoleh output yang baik atas pekerjaannya.

Meningkatkan kinerja dapat dilakukan dengan mengembangkan kompetensi. Mengembangkan kompetensi dapat dilakukan melalui pendidikan, pelatihan, kursus dan penataran. Dalam pasal 70 UU No. 4 tahun 2014 tentang ASN mengatur bahwa setiap ASN memiliki hak dan kesempatan untuk mengembangkan kompetensi. Kompetensi dan kapasitas seseorang tentunya dapat mempengaruhi output pekerjaan seseorang (Hazrita, 2014). Seseorang yang memiliki pengetahuan dan keterampilan dalam pengelolaan keuangan serta didukung dengan sikap yang mau terus belajar mengikuti perkembangan teknologi dan ilmu pengetahuan, tentunya mampu menghasilkan laporan keuangan yang lebih berkualitas.

\section{Kesimpulan}

Berdasarkan hasil penelitian dan pembahasan dapat diambil kesimpulan sebagai berikut.

1. Hasil pengujian variabel penerapan SIMDA terhadap kualitas laporan keuangan diperoleh nilai $p$ value sebesar 0,000 lebih kecil dari 0,05 maka dapat disimpulkan bahwa penerapan SIMDA berpengaruh terhadap kualitas laporan keuangan Kabupaten Minahasa Selatan.

2. Hasil pengujian variabel SAP terhadap kualitas laporan keuangan diperoleh nilai $p$ value sebesar 0,000 lebih kecil dari 0,05 maka dapat disimpulkan bahwa SAP berpengaruh terhadap kualitas laporan keuangan Kabupaten Minahasa Selatan.

3. Hasil pengujian variabel motivasi pegawai terhadap kualitas laporan keuangan diperoleh nilai $p$ value sebesar 0,001 lebih kecil dari 0,05 maka dapat disimpulkan bahwa motivasi pegawai berpengaruh terhadap kualitas laporan keuangan Kabupaten Minahasa Selatan.

4. Hasil pengujian variabel kompetensi SDM terhadap kualitas laporan keuangan diperoleh nilai $p$ value sebesar 0,005 lebih kecil dari 0,05 maka dapat disimpulkan bahwa kompetensi SDM berpengaruh terhadap kualitas laporan keuangan Kabupaten Minahasa Selatan.

\section{Saran}

Berdasarkan hasil penelitian diatas maka saran yang dapat diberikan adalah sebagai berikut.

1. Pengevaluasian terhadap sistem informasi yang diterapkan yakni SIMDA perlu dilakukan secara berkala guna memastikan sistem informasi yang digunakan sudah sesuai dengan kebutuhan pemerintah daerah sehingga laporan yang dihasilkan semakin berkualitas.

2. Sebaiknya semakin ditingkatkannya intensitas pelatihan pada para pengelola keuangan berupa sosialisasi dan bimbingan teknis yang berkaitan dengan implementasi standar akuntansi pemerintahan (SAP) sehingga pelatihan yang dilaksanakan dapat semakin meningkatkan pemahaman dan penerapan SAP.

3. Pemberian reward atas pekerjaan yang tercapai dapat dicoba sebagai alternatif untuk meningkatkan motivasi pegawai pengelola keuangan sehingga dapat meningkatkan prestasi kerja, dalam hal ini kualitas laporan keuangan semakin meningkat.

4. Pemerintah Kabupaten Minahasa Selatan sebaiknya dalam menempatkan SDM pengelola keuangan di tingkat SKPD disesuaikan dengan kompetensi SDM tersebut. Pengelola keuangan haruslah memiliki pengetahuan dan keterampilan di bidang akuntansi sehingga semakin meningkatkan pengelolaan keuangan dan penyusunan laporan keuangan pemerintah Kabupaten Minahasa Selatan.

\section{Daftar Pustaka}

Belkaoui, Ahmed-Riahi, .1985. Accounting Theory. $2^{\text {nd }}$ edition. San Diego, California: Harcourt Brace Jovanovich, Publishers.

BPK. 2016. Ikhtisar Hasil Pemeriksaan Semester (IHPS) I Tahun 2016. http://www.bpk.go.id

BPK. 2015. Pendapat BPK. http://www.pontianak.bpk.go.id

BPKP. 2017. Berita Seputar BPKP dan Pengawasan. http://bpkp.go.id

Davis, Fred D. 1989. Perceived Usefulness, Perceived Ease of Use, and User Acceptance of Information Technology, MIS Quarterly; Sep 1989; 13, 3; ABI/INFORM Global, page: 319-340. 
Hazrita, Fadilah. 2014. Pengaruh Kompetensi dan Sistem Akuntansi Terhadap Kualitas Pertanggungjawaban Laporan Keuangan pada Satuan Kerja di Lingkungan Kanwil Kementerian Agama Provinsi Riau.Jurnal Ilmu Sosial dan Ekonomi.Vol 9No. 1. April 2014, hal: 59-69. Riau: Program Studi Magister Akuntansi Pasca Sarjana Universitas Riau

Hery. 2017. Teori Akuntansi: Pendekatan Konsep dan Analisis. Jakarta: PT. Grasindo.

Jensen, Michael C. dan Meckling, William H. 1976. The Theory of The Firm: Manajerial Behaviour, Agency Cost, and Ownership Structure. Journal of Financial and Economics 3 (1976) page: 305360. North Holland Publish Company.

Jogiyanto HM. 2007. Sistem Informasi Keperilakuan. Yogyakarta: Andi Publisher.

Kabupaten Minahasa Selatan. 2016. Peraturan Bupati Minahasa Selatan No. 13 Tahun 2016 tentang Perubahan atas Peraturan Bupati Minahasa Selatan No. 7 Tahun 2014 tentang Kebijakan Akuntansi Kabupaten Minahasa Selatan.

Kadarisman. 2012. Manajemen Pengembangan Sumber Daya Manusia. Jakarta: Raja Grafindo Persada.

Maslow, Abraham H. 1943. A Theory of Human Motivation. Psychological Review, Vol. 50(4), page: 370-396.

Priyatno, Duwi. 2014. SPSS 22: Pengolah Data Terpraktis. Yogyakarta: Andi.

Republik Indonesia. 2003. Undang-Undang Nomor 17 Tahun 2003 tentang Keuangan Negara. Lembaran Negara RI Tahun 2003, Nomor 47. Jakarta.

Republik Indonesia. 2010. Peraturan Pemerintah Nomor 71 Tahun 2010 tentang Standar Akuntansi Pemerintahan. Lembaran Negara RI Tahun 2010, Nomor 123. Jakarta.

Republik Indonesia. 2014. Undang-Undang Nomor 5 Tahun 2014 tentang Aparatur Sipil Negara. Jakarta.

Sedarmayanti. 2017. Manajemen Sumber Daya Manusia, Reformasi Birokrasi dan Manajemen Pegawai Negeri Sipil. Bandung: PT. Refika Aditama.

Staubus, George J, .1954. An Accounting Concept of Revenue. PhD Dissertation. University of Chicago USA.

Spencer, M. Lely dan Spencer, Signe .1993. Competence at Work "Models for Superior Performance”. New York: John Willey \& Sons Inc 